\title{
TEKNOLOGI FERMENTASI, ALTERNATIF SOLUSI DALAM UPAYA PEMANFAATAN BAHAN PAKAN LOKAL
}

\author{
Wahyu Pamungkas \\ Loka Riset Pemuliaan dan Teknologi Budidaya Perikanan Air Tawar \\ Jl. Raya 2 Sukamandi, Subang 41256 \\ E-mail: baginfo_lrptbpat@yahoo.com; yhoe_pamungkas@yahoo.co.id
}

\begin{abstract}
ABSTRAK
Upaya pemanfaatan bahan baku pakan alternatif banyak dilakukan dengan menggunakan bahan baku pakan lokal yang mudah didapat dan biasanya berupa limbah yang belum termanfaatkan secara optimal. Akan tetapi, upaya pemanfaatan bahan baku pakan lokal tersebut masih mengalami kendala yaitu tingginya kandungan serat kasar, rendahnya kandungan protein kasar bahan baku, keseimbangan asam amino yang rendah, dan adanya zat anti nutrisi. Hal ini menyebabkan perlunya pengolahan bahan baku pakan lokal tersebut sebelum digunakan sebagai bahan pakan. Salah satu cara pengolahan yang dapat dilakukan adalah dengan melalui fermentasi. Secara umum, fermentasi menghasilkan produk yang lebih sederhana dan lebih mudah dicerna dari bahan asalnya. Melalui teknologi fermentasi, dapat dihasilkan perbaikan dan peningkatan nilai nutrisi bahan baku pakan lokal sehingga dapat dimanfaatkan secara optimal untuk bahan baku pakan ikan.
\end{abstract}

KATAKUNCI: bahan pakan lokal, fermentasi, limbah teknologi

\section{PENDAHULUAN}

Pakan merupakan komponen terbesar dari biaya produksi dalam kegiatan budidaya perikanan, yaitu mencapai 60\%-70\%. Permintaan pakan meningkat seiring dengan berkembangnya kegiatan budidaya perikanan. Akan tetapi harga bahan pakan konvensional sumber protein, seperti tepung ikan, dan bungkil kedelai berfluktuasi dan masih harus diimpor untuk memenuhi kebutuhan industri peternakan dan perikanan (Ginting \& Krisnan, 2006). Hal tersebut mendorong upaya untuk mencari bahan baku pakan alternatif yang tersedia secara lokal, berlimpah, dan terjaga kontinuitasnya serta dapat menggantikan atau mengurangi penggunaan tepung ikan dan bungkil kedelai.
Pemanfaatan bahan baku pakan alternatif telah banyak dilakukan untuk mengatasi masalah mahalnya mendapatkan bahan baku pakan sumber protein seperti tepung ikan dan bungkil kedelai. Upaya pemanfaatan bahan baku pakan alternatif banyak dilakukan dengan menggunakan bahan baku pakan lokal yang mudah didapat dan biasanya berupa limbah yang belum termanfaatkan secara optimal. Beberapa bahan baku pakan lokal yang mempunyai potensi sebagai bahan baku pakan alternatif adalah yang berasal dari limbah industri pertanian seperti bungkil kelapa sawit, ampas sagu, bungkil biji karet, bungkil kelapa, kopra, kulit buah kakao, daun rami, limbah tanaman pisang, limbah singkong, dan dedak padi (Mathius \& Sinurat, 2001) serta limbah peternakan seperti isi rumen (Wizna et al., 2008), limbah udang (Mathius \& Sinurat, 2001), limbah bulu ayam (Cortezi et al., 2008) dan sebagainya. Akan tetapi, upaya pemanfaatan bahan baku pakan lokal tersebut masih mengalami kendala yaitu tingginya kandungan serat kasar, rendahnya kandungan protein kasar bahan baku, keseimbangan asam amino yang rendah dan adanya zat anti nutrisi. Hal ini menyebabkan perlunya pengolahan bahan baku pakan lokal tersebut sebelum digunakan sebagai bahan pakan.

Berbagai pengolahan terhadap bahan pakan berserat tinggi telah banyak dilakukan untuk meningkatkan efisiensi penggunaan pakan, seperti pengolahan secara fisik, kimia, dan biologi atau kombinasinya (fermentasi). Menurut Kompiang et al. (1994), teknologi untuk meningkatkan mutu bahan pakan adalah dengan fermentasi. Secara umum semua produk akhir fermentasi biasanya mengandung senyawa yang lebih sederhana dan mudah dicerna daripada bahan asalnya (Laelasari \& Purwadaria, 2004). Lebih lanjut dinyatakan bahwa fermentasi juga berfungsi sebagai salah satu cara pengolahan dalam rangka pengawetan bahan dan cara untuk mengurangi bahkan menghilangkan zat racun yang dikandung suatu bahan serta adanya berbagai jenis mikroorganisme yang mempunyai kemampuan untuk mengkonversikan pati menjadi protein dengan penambahan nitrogen anorganik melalui fermentasi. 
Pemanfaatan bahan baku pakan lokal hasil limbah industri pertanian yang ditingkatkan nilai nutrisinya melalui teknik fermentasi diharapkan akan dapat mencukupi kebutuhan bahan baku sumber protein dan dapat mengurangi penggunaan tepung ikan dan bungkil kedelai yang masih impor. Optimalisasi penggunaan bahan baku pakan lokal akan dapat mengatasi masalah pakan yang menjadi bagian dalam rangkaian budidaya.

\section{POTENSI DAN KENDALA PEMANFAATAN}

Pemanfaatan bahan baku pakan alternatif telah banyak dilakukan yaitu dengan menggunakan bahan baku pakan lokal yang mudah didapat dan biasanya berupa limbah yang belum termanfaatkan secara optimal. Beberapa bahan baku pakan lokal yang mempunyai potensi sebagai bahan baku pakan alternatif adalah yang berasal dari limbah industri pertanian dan perkebunan seperti bungkil kelapa sawit, ampas sagu, bungkil biji karet, bungkil kelapa, kopra, kulit buah kakao, daun rami, limbah tanaman pisang, limbah singkong, dan dedak padi (Mathius \& Sinurat, 2001; Kamaruddin et al., 2008) serta limbah peternakan seperti isi rumen (Wizna et al., 2008), limbah udang (Mathius \& Sinurat, 2001), limbah bulu ayam (Cortezi et al., 2008) dan limbah industri seperti ampas kecap (Marzuqi et al., 2008).
Bahan baku pakan lokal mempunyai kandungan nutrisi yang potensial digunakan sebagai bahan baku pakan ternak maupun ikan. Beberapa bahan baku pakan lokal seperti ampas singkong, bungkil kelapa sawit, dan dedak halus dapat dijadikan sumber lemak maupun energi, sedangkan ampas tahu dapat digunakan sebagai sumber protein karena kandungan protein dan lemak pada ampas tahu yang tinggi yaitu protein $8,66 \%$; lemak $3,79 \%$; air $51,63 \%$; dan abu 1,21\% (Ahmad et al., 2000). Adapun Hartadi et al. (1990) menyatakan bahwa limbah udang memiliki kandungan nutrien yang cukup baik dan kandungan nutrien tepung limbah udang yaitu energi metabolis (ME) sebesar $1.190 \mathrm{kkal} / \mathrm{kg}$; protein kasar (PK) 43,4\%; kalsium (Ca) 7,05\%; dan fosfor (P) 1,52\%. Menurut Rasyaf (1994), tepung cangkang udang mengandung protein kasar antara $35 \%$ hingga $45 \%$ dan berkualitas baik, di samping itu, juga mengandung mineral (kalsium, fosfor, dan magnesium).

Namun demikian, upaya pemanfaatan bahan baku pakan lokal tersebut masih mengalami kendala yaitu tingginya kandungan serat kasar, rendahnya kandungan protein kasar bahan baku, keseimbangan asam amino yang rendah dan adanya zat anti nutrisi. Sue (2004) menyatakan bahwa kandungan protein kasar bungkil inti sawit sekitar 11,30\%$17,00 \%$ namun kandungan lemak dan serat kasar cukup

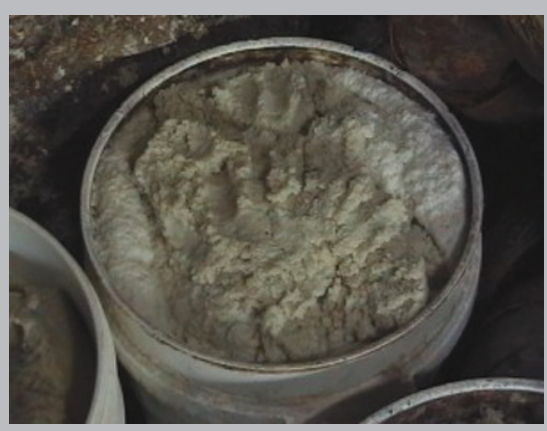

Gambar 1. Ampas tahu

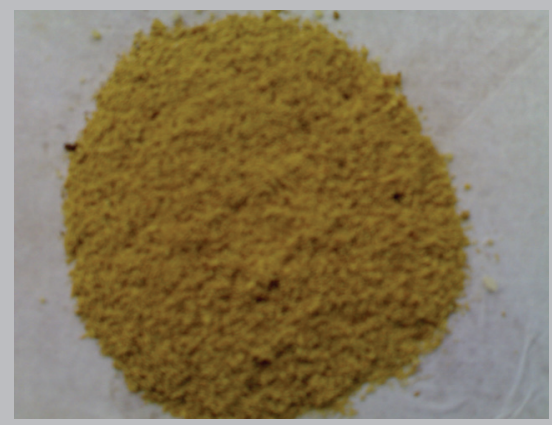

Gambar 4. Dedak

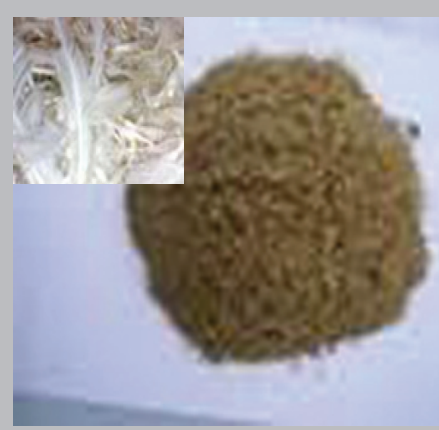

Gambar 2. Tepung bulu ayam

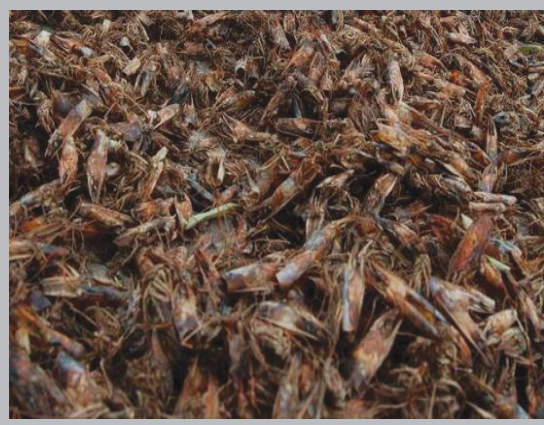

Gambar 5. Limbah kepala udang Sumber: Wiramiharja et al. (2007)
Gambar 3. Tepung tulang (Bone)

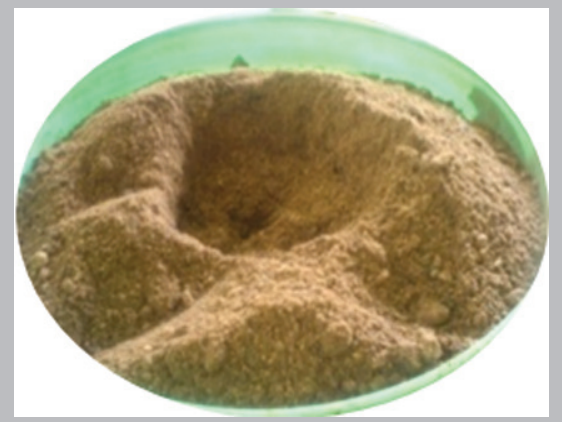

Gambar 6. Tepung bungkil inti sawit 
tinggi yaitu masing-masing sebesar 4,50\%-17,00\% dan $16 \%$ 23\%. Lemak yang tinggi akan menyebabkan ketengikan sehingga memperpendek daya simpan bahan pakan tersebut, sedangkan serat kasar yang tinggi akan menyebabkan bahan pakan sulit dicerna oleh ternak atau ikan (Kompiang et al., 1997). Ampas tahu yang merupakan sisa dari proses pengolahan susu kedelai yang tidak terlarut mempunyai kandungan vitamin dan mineral yang tidak komplit karena banyak yang hilang selama proses pengolahan meskipun dapat digunakan sebagai bahan pakan pengganti tepung kedelai (Wiramiharja et al., 2007). Lebih lanjut dinyatakan bahwa tepung bulu yang juga berpotensi digunakan sebagai bahan pakan ikan sumber protein mempunyai daya cerna yang rendah karena mengandung tingkat keratin yang tinggi, keras, berserabut, dan ikatan disulfide yang kuat. Selain itu, tingkat asam amino esensial, histidin, lisin, metionin, dan tryptophan yang kurang baik. Hal tersebut menyebabkan perlunya pengolahan bahan baku pakan lokal tersebut sebelum digunakan sebagai bahan pakan. Berbagai pengolahan terhadap bahan pakan dengan kandungan nutrisi yang rendah dan berserat tinggi telah banyak dilakukan untuk meningkatkan efisiensi penggunaan pakan, seperti pengolahan secara fisik, kimia, dan biologi atau kombinasinya (fermentasi). Secara umum semua produk akhir fermentasi biasanya mengandung senyawa yang lebih sederhana dan mudah dicerna daripada bahan asalnya (Laelasari \& Purwadaria, 2004).

\section{TEKNOLOGI FERMENTASI}

Fermentasi merupakan proses pemecahan senyawa organik menjadi senyawa yang lebih sederhana dengan melibatkan mikroorganisme. Menurut Ganjar (1983), fermentasi adalah suatu proses perubahan kimiawi dari senyawa-senyawa organik (karbohidrat, lemak, protein, dan bahan organik lain) baik dalam keadaan aerob maupun anaerob, melalui kerja enzim yang dihasilkan oleh mikroba. Fermentasi bahan pakan mampu mengurai senyawa kompleks menjadi sederhana sehingga siap digunakan larva. Selain itu, sejumlah mikroorganisme diketahui mampu mensintesis vitamin dan asamasam amino tertentu yang dibutuhkan oleh larva hewan akuatik.

Pada proses fermentasi diperlukan substrat sebagai media tumbuh mikroba yang mengandung zat-zat nutrisi yang dibutuhkan selama proses fermentasi berlangsung (Fardiaz, 1988). Lebih lanjut dinyatakan bahwa substrat dapat berupa substrat sumber karbon dan substrat sumber nitrogen. Selulosa sebagai salah satu sumber karbon dalam proses fermentasi telah banyak digunakan karena mudah didapat. Fardiaz (1988) juga menyatakan bahwa penggunaan selulosa sebagai sumber karbon tidak dapat digunakan secara langsung tetapi harus mengalami proses hidrolisis terlebih dahulu secara kimia atau enzimatik. Menurut Enari (1983) dalam Ekawati (1993), mekanisme hidrolisis selulosa secara enzimatis dapat dibagi menjadi dua tahap yaitu tahap aktivasi oleh enzim C1 (ekso- $\beta$-1.4 glukanase atau selulase) dilanjutkan dengan tahap hidrolisis oleh enzim Cx (endo- $\beta$-1.4 glukanase) dan $\beta$ glukosidase (Gambar 7).

$$
\text { C1 } \quad \text { Cx } \quad \beta \text {-glukosidase }
$$

Selulosa $\rightarrow$ selulosa reaktif $\rightarrow$ selobiosa $\rightarrow$ glukosa

Gambar 7. Mekanisme hidrolisis selulosa secara enzimatik (Ekawati,1993)

Selanjutnya pada proses fermentasi glukosa akan terbentuk asam piruvat dan dari bentuk asam piruvat akan diubah menjadi produk akhir yang spesifik untuk berbagai proses fermentasi (Fardiaz, 1988). Salah satu contoh proses fermentasi adalah fermentasi glukosa oleh bakteri asam laktat yang menghasilkan asam laktat dan produk lainnya (Gambar 8).

\section{Glukosa $\longrightarrow$ Asam laktat + etanol/asam asetat $+\mathrm{CO}_{2}$}

Gambar 8. Reaksi fermentasi glukosa oleh bakteri (Fardiaz, 1988)

Produk terfermentasi umumnya mudah diurai secara biologis dan mempunyai nilai nutrisi yang lebih tinggi dari bahan asalnya (Winarno et al., 1980). Hal tersebut selain disebabkan oleh sifat mikroba yang katabolik atau memecah komponen-komponen yang komplek menjadi lebih sederhana sehingga lebih mudah dicerna, tetapi juga dapat mensintesis beberapa vitamin yang komplek. Manfaat fermentasi antara lain dapat mengubah bahan organik kompleks seperti protein, karbohidrat, dan lemak menjadi molekul-molekul yang lebih sederhana dan mudah dicerna, mengubah rasa dan aroma yang tidak disukai menjadi disukai dan mensintesis protein. Manfaat lain dari fermentasi adalah bahan makanan lebih tahan disimpan dan dapat mengurangi senyawa racun yang dikandungnya, sehingga nilai ekonomis bahan dasarnya menjadi jauh lebih baik. Rusdi (1992) menyatakan bahwa hasil fermentasi sangat bergantung pada bahan pakan sebagai bahan dasar (substrat), macam mikroba atau inokulum dan kondisi lingkungan yang sangat mempengaruhi pertumbuhan dan metabolisme mikroba tersebut. 


\section{PERKEMBANGAN RISET FERMENTASI BAHAN PAKAN LOKAL}

Teknologi fermentasi banyak dilakukan untuk peningkatan nilai gizi bahan pakan lokal atau asal limbah, misalnya melalui fermentasi dengan menggunakan Aspergillus niger (Nurhayati, 2005). Laporan penelitian sebelumnya menunjukkan teknologi fermentasi dapat meningkatkan kandungan protein pada ketela pohon, bungkil kelapa (Purwadaria et al., 1997), sagu, bungkil inti sawit (Kompiang et al., 1997) dan campuran onggok kotoran ayam (Sjofjan et al., 2002). Teknologi fermentasi bahan pakan lokal telah banyak dilakukan di bidang pakan ternak yang merupakan salah satu upaya pemanfaatan bahan baku pakan lokal sebagai bahan pakan ternak. Fermentasi dengan menggunakan kapang memungkinkan terjadinya perombakan komponen bahan yang sulit dicerna menjadi lebih mudah dicerna, sehingga diharapkan dapat meningkatkan nutrisinya. Fermentasi asam laktat pada kedelai terbukti menghilangkan kandungan sukrosa, menurunkan kadar rafinosa, aktivitas penghambat tripsin, dan faktor penghambat absorpsi lemak. Adapun fermentasi dengan Aspergillus oryzae terbukti meningkatkan kadar protein dan kadar peptida berukuran kecil serta menghilangkan penghambat tripsin (Irianto, 2003). Fermentasi biji rami (Linum usitatissimum) dengan inokulum bakteri asam laktat (Lactobacillus acidophilus) mampu mengurangi zat anti nutrisi (asam pitat) dan kandungan tannin dalam biji rami dari 2,45\% menjadi 1,32\% (Mukhopadhyay \& Ray, 2005).

Fermentasi sagu dan isi rumen dengan menggunakan Bacillus amyloliquefaciens menghasilkan penurunan kandungan serat kasar dari 23,73\% menjadi 16,56\% dan meningkatnya protein kasar dari 9,11\% menjadi $16,37 \%$ dengan lama waktu fermentasi 9 hari, dosis $2 \%$ dan suhu $40^{\circ} \mathrm{C}$ (Wizna et al., 2008). Lebih lanjut dinyatakan bahwa fermentasi campuran sagu dan isi rumen pada pakan unggas dengan menggunakan Bacillus amyloliqufaciens meningkatkan kandungan asam amino dari 2,42\% sampai 4,43\%. Bacillus amyloliquefaciens juga diketahui sebagai penghasil enzim selulase, di mana enzim tersebut dapat merombak dan mengubah molekul yang masih komplek menjadi komponen molekul yang lebih sederhana. Fermentasi pada limbah singkong dengan menggunakan Bacillus amyloliquefaciens sebagai inokulum dapat meningkatkan kandungan protein kasar hingga 360\% dan mengurangi kandungan serat kasar hingga 32\% (Wizna et al., 2005).

Mirwandhono \& Siregar (2004) melaporkan bahwa fermentasi menggunakan Aspergillus niger (3\% dari bahan kering bungkil inti sawit (BIS) secara nyata mampu meningkatkan kandungan protein dari 15,03\% menjadi $18,50 \%$. Selanjutnya dilaporkan bahwa penggunaan $2 \%$ Aspergillus niger pada fermentasi BIS secara nyata meningkatkan kandungan energi bruto pada BIS yaitu dari $1.661 \mathrm{kkal} / \mathrm{kg}$ (BIS sebelum fermentasi) menjadi 1.837 $\mathrm{kkal} / \mathrm{kg}$ (setelah fermentasi). Hasil penelitian $\mathrm{Ng} \&$ Chen (2004) menunjukkan bahwa bungkil kelapa sawit yang difermentasi oleh Trichoderma koningii menghasilkan peningkatan kandungan protein kasar, yaitu dari $17 \%$ menjadi 32\%. Penelitian Phong et al. (2004) tentang pengkayaan protein pada onggok menggunakan Aspergillus niger dapat dilihat pada Tabel 1 .

Tabel 1. Kandungan nutrisi onggok sebelum dan sesudah difermentasi dengan Aspergillus niger

\begin{tabular}{lcc}
\hline \multirow{2}{*}{$\begin{array}{c}\text { Kandungan nutrisi } \\
\text { (\%) }\end{array}$} & \multicolumn{2}{c}{ Fermentasi } \\
\cline { 2 - 3 } & Sebelum & Setelah \\
\hline Bahan kering & 55,20 & 64,80 \\
Protein kasar & 2,40 & 9,80 \\
Protein murni & 1,10 & 6,40 \\
Serat kasar & 7,20 & 6,80 \\
Lemak kasar & 3,00 & 4,40 \\
Abu & 2,50 & 2,40 \\
HCN (mg/kg BK) & 14,00 & 7,00 \\
\hline
\end{tabular}

Dari penelitian tersebut disimpulkan bahwa onggok yang difermentasi Aspergillus niger dengan penambahan $1 \%$ ammonium sulfat meningkatkan protein murni dari $1,1 \%$ menjadi $6,4 \%$ dalam BK.

Hasil penelitian Nurhayati (2005) menunjukkan bahwa kandungan abu, protein kasar, Ca, dan $\mathrm{P}$ mengalami peningkatan setelah dilakukan fermentasi, sebaliknya kandungan LK, pati, gula, dan ME mengalami penurunan. Penelitian fermentasi campuran bungkil inti sawit dan onggok menggunakan Trichoderma harzianum yang dilakukan oleh Indariyanti et al. (2011) menunjukkan bahwa waktu fermentasi terbaik diperoleh pada 8 hari inkubasi dengan menghasilkan penurunan serat kasar sebesar $45 \%$ dan meningkatkan protein dari $12 \%$ menjadi 16\%-17\% kandungan protein kasar.

Beberapa hasil penelitian fermentasi bahan pakan yang secara nyata menghasilkan peningkatan nilai nutrisi bahan pakan menunjukkan bahwa teknologi fermentasi dapat meningkatkan penggunaan bahan baku pakan lokal yang mempunyai nilai nutrisi rendah sebelum difermentasi menjadi bahan pakan yang dapat digunakan sebagai bahan pakan ternak ataupun ikan yang mempunyai nilai nutrisi yang baik dan dapat dimanfaatkan oleh ikan. Amri (2007) 
menyatakan bahwa penggunaan bungkil inti sawit yang difermentasi dengan Rhizopus oligosporus sebanyak $18 \%$ dalam pakan ikan mas secara nyata meningkatkan jumlah konsumsi pakan, pertambahan bobot tertinggi, dan menurunkan konversi pakan. Adapun Jaelani (2007) melaporkan bahwa penggunaan BIS yang difermentasi menggunakan kapang Trichoderma reesei dapat dilakukan sampai taraf $15 \%$ dalam ransum ayam pedaging tanpa mengganggu bobot badan, konsumsi, dan konversi ransum, serta persentase bobot karkas. Hasil penelitian Hadadi et al. (2007) juga menunjukkan bahwa pakan dengan bahan baku limbah sawit yang difermentasi dengan enzim rumen dapat digunakan untuk pembesaran ikan nila, meskipun belum dapat menyamai pakan yang menggunakan kedelai. Namun dari segi harga, pakan ini lebih murah sehingga dapat dijadikan sebagai pakan alternatif.

\section{PENUTUP}

Teknologi fermentasi mampu meningkatkan atau memperbaiki nilai nutrisi bahan baku pakan lokal sehingga dapat dimanfaatkan sebagai bahan baku pakan ikan. Kandungan serat kasar yang tinggi dan rendahnya nilai protein bahan pakan lokal yang merupakan salah satu kendala dalam pemanfaatannya, dapat diperbaiki dengan melalui teknik fermentasi. Fermentasi bahan baku pakan dapat menurunkan kadar serta kasar, meningkatkan nilai protein kasar dan menghilangkan zat anti nutrisi bahan baku pakan lokal. Teknologi fermentasi merupakan salah satu alternatif solusi dalam pemanfaatan bahan baku pakan lokal secara optimal.

\section{DAFTAR ACUAN}

Ahmad, T., Rachmansyah, \& Palinggi, N.N. 2000. The availability and use of fish feed local ingredients for humpback grouper grow-out. Proceeding of Regional Workshop on Managemen Strategies for Sustainable sea Farming and Grouper. Aquaculture, NACA, Bangkok, Thailand, p. 90-120.

Amri, M. 2007. Pengaruh bungkil kelapa sawit pada pakan ikan mas (Cyprinus carpio). J. Ilmu-ilmu Pertanian Indonesia, 9(1): 71-76.

Cortezi, M., Contiero, J., De Lima, C.J.B., Lovaglio, R.B., \& Monti, R. 2008. Characterization of a feather degrading by Bacillus amyloliquefaciens.

I.G.A. 1993. Pemanfaatan bonggol pisang untuk produksi enzim selulase dari Aspergillus niger dan Trichoderma reesei. Tesis. Program Pascasarjana. Institut Pertanian Bogor, $109 \mathrm{hlm}$.
Fardiaz, S. 1998. Fisiologi Fermentasi. Bogor: Pusat Antar Universitas Lembaga Sumberdaya Informasi IPB.

Gandjar, I. 1983. Perkembangan mikrobiologi dan bioteknologi di Indonesia. Mikrobiologi di Indonesia. PRHIMI, hlm. 422-424.

Ginting, S.P. \& Krisnan, R. 2006. Pengaruh fermentasi menggunakan beberapa strain Trichoderma dan masa inkubasi berbeda terhadap komposisi kimiawi bungkil inti sawit. Seminar Nasional Teknologi Peternakan dan Veteriner, hlm. 939-944.

Hadadi, A., Herry, Setyorini, A., Surahman, \& Ridwan, E. 2007. Pemanfaatan limbah sawit untuk bahan pakan ikan. J. Budidaya Air Tawar, 4(1): 11-18.

Handoko, H. 2010. Isolasi dan karakterisasi enzim pendegradasi serat peningkat kualitas bungkil inti sawit untuk pakan ayam pedaging. Tesis. Bogor. Sekolah Pascasarjana Institut Pertanian Bogor.

Indariyanti, N., Jusadi, D., \& Utomo, N.B.P. 2011. Evaluasi kecernaan campuran BIS dan onggok yang difermentasi dengan Trichoderma harzianum untuk pakan ikan nila Oreochromis sp. Tesis. Program Pascasarjana Institut Pertanian Bogor, $29 \mathrm{hlm}$.

Irianto, A. 2003. Probiotik Akuakultur. Gadjah Mada University Press. Yogyakarta, $125 \mathrm{hlm}$.

Jaelani, A. 2007. Peningkatan kualitas bungkil inti sawit oleh kapang Trichoderma reesei sebagai pendegradasi polisakarida mannan dan pengaruhnya terhadap penampilan ayam pedaging. Disertasi. Bogor. Sekolah Pascasarjana Institut Pertanian Bogor.

Kamaruddin, Usman, dan Tangko, A.M. 2008. Persiapan dan penyusunan bahan baku lokal untuk formulasi pakan ikan. Media Akuakultur, 3(2): 150-156.

Kompiang, I.P., Purwadaria, T., Hartati, T., \& Supriyati. 1997. Bioconversion of sago (Metroxylon sp.) waste. Current status of Agricultural Biotechnology in Indonesia. A. Darusmna, Kompiang, I.P., \& Moeljoprawiro, S. (Eds.). AARD Indonesia, p. 523-526.

Kompiang, I.P., Sinurat, A.P., Kompiang, S., Purwadaria, T., \& Darma, J. 1994. Nutrition value of protein enriched cassava: Cassapro. J. Ilmu Ternak dan Veteriner, 4(2): 107-112.

Laelasari \& Purwadaria, T. 2004. Pengkajian nilai gizi hasil fermentasi mutan aspergillus niger pada subtrat bungkil kelapa dan bungkil inti sawit. Biodiversitas, 5(2): 48-51.

Marzuqi, M., Giri I.N.A., Agustina, E., \& Suwirya, K. 2008. Pengaruh tepung ampas kecap sebagai substitusi tepung ikan dalam pakan terhadap pertumbuhan 
dan nilai kecernaan juvenile ikan kerapu macan (Epinephelus fuscoguttatus). J. Perikanan UGM, IX(2): 254-260.

Mathius, I.W. \& Sinurat, A.P. 2001. Pemanfaatan Bahan Pakan Konvensional Untuk Ternak. Balai Penelitian Ternak Bogor, Bogor.

Mathius, I.W., Sinurat, A.P., Manurung, B.P., Sitompul, D.M., \& Azmi. 2005. Pemanfaatan produk fermentasi lumpur bungkil sebagai bahan pakan sapi potong. Seminar Nasional Teknologi Peternakan dan Veteriner, hlm. 153161.

Mirwandhono, E. \& Siregar, Z. 2004. Pemanfaatan hidrolisat tepung kepala udang dan limbah kelapa sawit yang difermentasi dengan Aspergillus niger, Rizhopus oligosporus, dan Trichoderma viridae dalam ransum ayam pedaging [laporan penelitian]. Medan. Universitas Sumatera Utara Digital Library.

Mukhopadhyay, N. \& Ray, A.K. 2005. Effect of fermentation apparent total and nutrient digestibility of Linseed, Linum usitatissimum, meal in Rohu, Lobeo rohita, fingerlings. Acta Ichthyologica Et Piscatoria, 35(2): 7378.

Ng, W.K. \& Chen, M.I. 2004. Researching the use of palm kernel cake in aquaculture feeds. Fish Nutrition laboratory, University Sains Malaysia, Penang.

Nurhayati. 2005. Evaluasi nutrisi campuran bungkil inti sawit dan onggok yang difermentasi menggunakan Aspergillus niger sebagai bahan pakan alternatif. Tesis. Program Pascasarjana Universitas Brawijaya. Malang, 71 hlm.

Rasyaf. 1994. Makanan Ayam Broiler. Penerbit Kanisius, Yogyakarta.

Rusdi, U.D. 1992. Fermentasi konsentrat campuran bungkil biji kapok dan onggok serta implikasi efeknya terhadap pertumbuhan ayam broiler. Disertasi. Universitas Padjadjaran. Bandung.

Sjofjan, O., Surisdiarto, Irfan, D., \& Aulanni’am. 2002. Penggunaan fermentasi campuran onggok dan kotoran ayam pada pakan ternak unggas. J. Ilmu-Ilmu Hayati, 14: 66-73.

Sue, T.T. 2004. Quality and characteristics of Malaysian palm kernel cakes/expellers. http:// www.plmoils.mpob.gov.my/webbased/pod34-tang.pdf (diakses pada 3 Desember 2004).

Phong, N.V., Hoa Ly, N.T., Nhac, N.V., \& Hang, D.T. 2004. Protein enrichment of cassava by-product using Aspergillus niger and feeding the product to pigs. Hue University of Agriculture and Forestry. http:// www.mekarn.org/sarec03/phong\%20hue.htm. (diakses pada 14 Januari 2005).

Winarno, F.G., Fardiaz, S., \& Fardiaz, D. 1980. Pengantar teknologi pangan. Penerbit PT Gramedia. Jakarta.

Wiramiharja, Y., Hernawati, R., Harahap, I.M., \& Niwa, Y. 2007. Nutrisi dan bahan pakan ikan budidaya. Freshwater Aquaculture Development Project. Balai Budidaya Air Tawar Jambi, Japan International Cooperation Agency, p. 100.

Wizna, Abbas, H., Rizal, Y., Kompiang, I.P., \& Dharma, A. 2005. The potential of cellulolytic bacteria Bacillus sp. From forest litter in improving the quality of cassava waste as feed and its applications toward improving the productivity of poultry. HB XIII project research report. Faculty of Animal Husbandry, Andalas University, Padang.

Wizna, Abbas, H., Rizal, Y., Kompiang, I.P., \& Dharma, A. 2008. Improving the quality of sago pith and rumen content mixture as poultry feed through fermentation by Bacillus amyloliquefaciens. Pakistan J. of Nutrition, 7(2): 249-254. 